\title{
EPISTEMOLOGI RASIONALISME RENE DESCARTES DAN RELEVANSINYA TERHADAP PENAFSIRAN AL-QUR`AN
}

\author{
Mochammad Arifin \\ Universitas Islam Negeri (UIN) Walisongo Semarang \\ e-mail: moch_arifin@outlook.com \\ Diterima 15 Agustus 2018 | Direview 20 Nopember 2018 | Diterbitkan 01 Desember 2018

\begin{abstract}
This article discusses about rationalism epistemology by Rene Descartes — modern philosopher — and his relevance to the Qur anic exegesis. A study about epistemology is the perspective which is urgent in developing science in the future. The meaning of epistemology is the science methodology to express the rasionalism by Rene Descartes from the source, methods, and validity. This study found that the sources of rationalism by Rene Descartes is rationality; the methods of rasionalism is doubtful, intuition and deduction; the validity is measured by coherence theory. The result of this study has relevance to the Qur an exegesis. The relevance is in the rationality, or in Qur anic exegesis it is called tafsir bi al-ra 'yi or tafsir bi al-'aqli. This interpreting isn't only answer the issue which is up to date, but also as a new way in approaching the Qur an through modern social sciences, like hermeneutica, stilistica, antropology, sosio-linguistic, and fenomenology.
\end{abstract}

Keywords: Epistemology, rasionalism, Rene Descartes, Qur`anic exegesis.

Abstrak

Artikel ini membahas tentang epistemologi rasionalisme oleh Rene Descartes - filsuf modern — dan relevansinya dengan penafsiran Al-Quran. Sebuab studi tentang epistemologi adalab perspektif yang sangat mendesak dalam mengembangkan ilmu pengetahuan di masa depan. Arti epistemologi adalah metodologi sains untuk mengekspresikan rasionalisme oleh Rene Descartes dari sumber, metode, dan validitas. Studi ini menemukan bahwa sumber rasionalisme oleh Rene Descartes adalah rasionalitas; metode rasionalisme diragukan, intuisi dan deduksi; validitas diukur dengan teori koherensi. Hasil penelitian ini memiliki relevansi dengan tafsir Al-Quran. Relevansinya ada dalam rasionalitas, atau dalam tafsir Al-Qur'an disebut tafsir bi al-ra 'yi atau tafsir bi al-'aqli. Penafsiran ini tidake hanya menjawab masalah yang terkini, tetapi juga sebagai cara baru dalam mendekati Al-Quran melalui ilmu sosial modern, seperti hermeneutica, stilistica, antropologi, sosio-linguistik, dan fenomenologi.

Kata Kunci: Epistemology, rasionalisme, Rene Descartes, Tafsir Qur'an.

\section{Pendahuluan}

Allah Subhạnabu wa Ta'ālà menjadikan manusia di muka bumi ini sebagai khalifah. Penentuan ini tidak lain karena manusia diberi kecerdasan nalar yang tidak dimiliki oleh makhluk lain. Dengan kecerdasannya, manusia diharapkan dapat mengatasi problematika kehidupan umat baik dari aspek agama, sosial budaya maupun politik yang kemudian menjadi lebih baik dan ter-manage secara kondusif. Upaya mengoptimalkan potensi daya pikir yang dimilikinya, lantas membuat manusia mencapai pada strata martabat yang mulia. Sebaliknya, jika ia tidak mampu mengaktifkan fungsi akalnya dengan baik, maka tak ubahnya ia seperti hewan, bahkan lebih sesat.

Terkait dengan fungsi akal itu sendiri, al-Qur`an telah mengisyaratkan melalui ayatayat sucinya dengan menggunakan formulasi kata yang sangat variatif. Ada kalanya formulasi kata itu diejawantahkan dengan bentuk ya'qilün, yafqabün, yatafakkarün, yanzurün, yubșirün, ya'tabirün, yatadabbarün, ya'lamün dan yatadhakkarün. Dan ada kalanya pula berupa kata $\bar{u} l \grave{l}$ alalbāb, ülì al-abșār dan ūlì al-nubā. Kesemuanya itu menunjukkan bahwa akal memainkan peran yang urgen dalam menentukan berbagai macam sikap realitas kehidupan.

Berangkat dari urgensi tentang peran dan fungsi akal tersebut, kemudian muncul suatu aliran yang mengusung bahwa akal merupakan satu-satunya sumber pengetahuan untuk memperoleh kebenaran yang konkret. Episteme yang mereka bangun adalah pengetahuan atau kesaksian yang bersumber dari luar akal manusia identik bernuansa khayal dan bersifat irasional. Semisal pengetahuan yang diperoleh melalui indra penglihatan, bahwa laut yang kita lihat dari arah kejauhan, maka ujungnya akan tampak menyatu dengan langit, padahal hakikatnya tidak begitu. Oleh karena itu, kebenaran sesungguhnya didasarkan pada nalar 
yang sehat. Dan mereka yang berparadigma seperti itu disebut sebagai orang yang menganut paham rasionalisme.

Dalam catatan sejarah menunjukkan bahwa tidak sedikit tokoh-tokoh yang lahir dari paham rasionalisme. Di antaranya adalah Rene Descartes (1596-1650 M), Blaise Pascal (1623-1662 M), Benedictus de Spinoza (1632-1677 M), Nicholas Malerbranche (1638-1775 M), Gotiefried Wilhelm von Leibniz (1646-1716 M) dan Christian Wolff (1679-1754 M). Dari sekian banyak deretan tokoh rasionalisme ini, penulis bermaksud meng-cover pemikiran sebagian dari mereka, yaitu Rene Descartes. Limitasi ini dimaksudkan agar kajian lebih fokus dan terarah dalam mengungkap pemikiran seorang tokoh. Pemilihan obyek kajian ini beralasan bahwa Descartes merupakan tokoh yang mempunyai pengaruh besar bagi perkembangan filsafat dan pemikir sesudahnya. Bahkan ia dinobatkan sebagai bapak filsafat modern.

Pemikiran Descartes, dalam tulisan ini akan dikupas dalam perspektif filsafat ilmu melalui tinjauan epistemologi. Diskursus epistemologi merupakan sesuatu yang penting dalam upaya pengembangan sebuah keilmuan di masa mendatang. Epistemologi yang dimaksudkan dalam tulisan ini adalah metodologi keilmuan yang berupaya mengkaji pemikiran Descartes dari sisi sumber pemikirannya, metode, dan validitas (verifikasinya). ${ }^{1}$ Di sisi lain, tulisan ini juga berupaya mencari titik relevansi rasionalitas Descartes dalam ranah penafsiran al-Qur`an.

\section{Sejarah Perkembangan Rasionalisme: Tinjauan Singkat}

Rasionalisme adalah sebuah paham filsafat ilmu yang berpandangan bahwa akal memiliki kekuatan independen untuk dapat mengetahui dan mengungkap prinsip-prinsip pokok dari alam, atau terhadap suatu kebenaran menurut nalar yang sehat. ${ }^{2}$ Munculnya paham ini dilatar belakangi oleh keinginan manusia untuk membebaskan diri dari segala pemikiran tradisional yang pernah diterimanya, namun ternyata hal itu tidak mampu mengakomodir sebuah fenomena pengetahuan yang dihadapi dengan baik dan akurat.

Perintis awal paham rasionalisme adalah Heraclitus, seorang pionir yang getol menggembar-gemborkan akal sebagai sumber utama ilmu pengetahuan melebihi panca indra yang lain. Kemudian pada masa skolastik, rasionalisme berkembang di bawah peran kontribusi tokoh-tokoh seperti Socrates, Plato dan Aristoteles. Puncaknya adalah ketika Aristoteles menangkis serangan pemikiran aliran Sufastaiyyun (subyektifisme) yang menyebarkan pandangan bahwa suatu perkara apapun dianggap baik manakala manusia menganggapnya baik. Dengan kata lain, manusia adalah penentu terhadap segala sesuatu. Aristoteles kemudian meresponsnya dengan memperkenalkan rasionalisme serta menyusun kaidah ilmu logika secara sistematis dalam karyanya yang populer, yaitu Organaon. Upaya Aristoteles ini lalu dilanjutkan oleh Rene Descartes, sosok yang dikenal sebagai bapak filsafat modern. ${ }^{3}$

Selanjutnya, pada periode modern muncul filsafat Descartes yang masyhur disebut dengan "rasionalisme". Paham rasionalisme terus berlanjut hingga filsafat idealisme Jerman, bahkan hingga filsuf Edmund Husserl, pendiri paham fenomenologi. Husserl pada masa perkembangan intelektualnya pernah melakukan radikalisasi atas konsep cogito yang digagas oleh Descartes. Dalam bidang epistemologi, metode filsafat Descartes disebut dengan "fondasionalisme", yaitu sebuah paham yang mengatakan bahwa semua pengetahuan bertolak dari sebuah dasar atau fondasi yang kebenarannya bersifat pasti dan berfungsi sebagai tolok ukur bagi semua pengetahuan lainnya.

1John L. Esposito (ed.), The Oxford Encyclopedia of the Modern Islamic World, jilid III (New York: Oxford University Press, t.th), h. 408.

${ }^{2}$ Loreus Bagus, Kamus Filsafat, (Jakarta: Gramedia Pustaka Utama, 2002), 929.

${ }^{3}$ Muhammad Bahar Akkase Teng, "Rasionalis dan Rasionalisme dalam Perspektif Sejarah", dalam Jurnal Ilmu Budaya, Vol. 4, No. 2, Desember 2016, h. 15-16. 
Rasionalisme yang berkembang pada masa Descartes berlangsung secara signifikan dan bisa dikatakan mencapai puncak kematangannya. Pada masa ini ditandai dengan penggunaan nalar (rasio) secara ekslusif untuk menemukan suatu kebenaran. Terbukti, upaya ini tidaklah sia-sia, bahkan mampu memberikan tambahan ilmu pengetahuan yang sangat berkualitas akibat perkembangan pesat dari ilmu-ilmu alam. Realitas ini membuat orangorang semakin percaya terhadap peran akal sebagai sumber kebenaran secara mutlak. Mereka akhirnya berpandangan bahwa akal merupakan faktor fundamental dalam suatu pengetahuan. ${ }^{4}$

Singkat kata, rasionalisme adalah antitesa dari abad pertengahan dan sekaligus lahirnya paham humanisme, akibat adanya timbul rasa kekurang-puasan terhadap paham gereja. Rasionalisme juga merupakan paham kedua dalam struktur pemikiran modern yang paling menonjol setelah empirisme.

\section{Sketsa Biografis Rene Descartes}

Rene Descartes merupakan sederet tokoh rasionalisme yang diberi gelar predikat sebagai bapak filsafat modern. Ia lahir di Prancis pada 31 Maret 1596, tepatnya di La Haye, sebuah kota kecil yang terletak di antara Tours dan Poitiers. Kota ini kemudian berganti nama menjadi Descartes. Hal ini sebagai bentuk apresiasi atas jasa-jasa Descartes yang telah mengharumkan tanah kelahirannya di kancah dunia melalui pemikiran-pemikiran filsafat dikembangkannya bagi generasi yang akan datang. ${ }^{5}$

Descartes lahir dari kalangan keluarga bangsawan. Ayahnya, Joachim, merupakan staf anggota parlemen di Paris. Sementara ibunya, Jeanne Brochard, adalah berasal dari keluarga saudagar dan pegawai kerajaan. Semasa kecil, Descartes akrab disapa teman-temannya dengan panggilan nama Latin, yaitu Renatus Cartesius. ${ }^{6}$ Sejak usia 1 tahun, ia telah ditinggal mati ibunya akibat menderita penyakit tuberculosis. Faktor genetik dari ibunya ini tampaknya juga menjalar ke tubuh Descartes, sehingga sejak kecil fisiknya terlihat sangat lemah. Pasca kematian ibunya, Descartes tinggal bersama sang nenek dan baby sister, sebab ayahnya sering kali keluar kota terkait urusan profesi yang digelutinya.

Menginjak usia ke-4 tahun, sang ayah memutuskan untuk kawin dan dari perkawinannya ini diberi keturunan 4 anak. Dari sini, Descartes seakan-akan tidak pernah mendapatkan belaian kasih sayang dari orang tuanya sendiri. Sebagai bentuk pelampiasan, Descartes banyak menghabiskan hari-harinya dengan mengurung atau menyendiri. Dalam kesendiriannya ini, ia kerap kali berkontemplasi tentang prospek masa depannya kelak. Begitu seringnya berkontemplasi, akal Descartes semakin terasah tajam dalam berpikir. Dan pada saat itu ia terbilang sebagai anak yang genius. ${ }^{8}$

Pada tahun 1604, tepat di usianya yang ke 8 tahun, Descartes memulai karir intelektualnya di Collège Royal de La Flèche. Di instansi ini, Selama 8 tahun-1612 M-ia dengan sungguh-sungguh mempelajari disiplin ilmu Logika, Filsafat, Matematika dan Fisika. ${ }^{9}$ Descartes selama hidupnya memuji tempat belajarnya ini sebagai lembaga pendidikan paling terbaik di Eropa, sebab kurikulumnya berpusat pada logika Aristoteles, metafisika, fisika dan etika, bahasa dan literatur yang didesain dalam kerangka tradisi skolastisisme.

\footnotetext{
${ }^{4}$ Ibid, h. 16.

5Paul Strathern, 90 Menit Bersama Descartes, terj. Fans Kowa, (Jakarta: Erlangga, 2001), h. 4-5.

"Sholehah Yaacob dan Hairunnaja Najmuddin, "Rene Descartes dan Metode Cogito", dalam Jurnal Ushuluddin, vol. 27, 2008, h. 125.

${ }^{7}$ Tuberculosis adalah penyakit infeksi yang dapat menyerang berbagai organ atau jaringan tubuh. Penyakit ini sudah ada sejak ribuan tahun sebelum masehi. Menurut hasil penelitian, tuberculosis sudah ada sejak zaman Mesir kuno yang dibuktikan dengan penemuan mumi. Bahkan penyakit ini juga sudah ada pada kitab pengobatan Cina 'pen tsao' sekitar 5000 tahun yang lalu. Lihat, Widoyono, Penyakit Kronis: Epidemiologi, Penularan, Pencegahan dan Pemberantasannya, (Jakarta: Erlangga, t.th), h. 13.

${ }^{8}$ Sholehah Yaacob dan Hairunnaja Najmuddin, "Rene Descartes dan Metode Cogito", h. 126.

${ }^{9}$ Franz Magnis Suseno, Filsafat sebagai Ilmu Kritis, (Yogyakarta: Kanisius, 2002), h. 71.
} 
Pada tahun 1615, Descartes bertolak dari Collège Royal de La Flèche untuk kemudian melanjutkan studinya di Poitiers University hingga memperoleh gelar sarjana di bidang ilmu hukum di tahun 1616. Descartes kemudian melepaskan segala macam ilmu pengetahuan yang telah dipelajarinya, sebab menurutnya ilmu-ilmu itu belum berhasil menetapkan fondasi yang kebenarannya absolut. Dari sini, Descartes mulai meragukan segalanya, termasuk dirinya sendiri. Ia kemudian mulai mencari pengetahuan yang pasti berdasarkan rasionya. Bahkan, pada akhirnya ia mendeklarasikan bahwa hakikat sebuah pengetahuan adalah yang diperoleh melalui rasio.

Selanjutnya, pada tahun 1618-1628, Descartes mengikuti latihan kemileteran di Belanda dan berhasil menjadi anggota pasukan Duck de Baviera. Di Belanda inilah Descartes merasakan iklim kebebasan berpikir yang tidak pernah ia rasakan di negara lain. Oleh karena itu, tidak heran jika kemudian ia betah berdomisili selama 20 tahun (1629-1649) di negara yang pernah menjajah Indonesia itu. Di negara ini pula, Descartes dengan sangat leluasa menyusun serta mengorbitkan karya-karyanya di bidang ilmu dan filsafat. Di antara karya-karyanya adalah Discours de la Methode (1637), Meditation Metphysiques (1641), Principes de la Philosophie (1644) dan Traite des Passions de l'Ame (1649).

Pada tahun 1649, Descartes meninggalkan Belanda dan berangkat ke Stockholm, Swedia, atas undangan Ratu Christina yang sebelumnya sempat ragu untuk menghadirinya. Di sana ia bergabung dengan sekelompok cendekiawan yang dikumpulkan oleh Ratu Christina untuk mengajarkan filsafat di istana kerajaan. Pada saat itu, musim dingin di sana sangat tidak menguntung Descartes untuk kondisi kesehatannya. Sejak masih duduk di bangku sekolah, ia terbiasa bangun tidur menjelang siang, sementara sang Ratu menyuruhnya untuk hadir di lokasi seetiap hari pada pukul 5 pagi. Descartes tidak cukup kuat fisiknya menghadapi sistem kerja yang diterapkan tersebut. Akibatnya, ia terserang pneumonia pada Januari 1650. Dan pada bulan berikutnya, yakni 11 Pebruari 1650, ia meninggal dunia. Pada tahun 1667, tulang-belulangnya dipindahkan ke Prancis. ${ }^{10}$

\section{Rasionalisme Rene Descartes: Sebuah Kajian Epistemologis}

Sebelum masuk ke ranah epistemologi yang digunakan sebagai pendekatan untuk mengkaji pemikiran Descartes, maka di sini akan dideskripsikan terlebih dahulu definisi epistemologi itu sendiri. Secara etimologis, epistemologi berasal dari bahasa Yunani episteme yang berarti pemahaman atau pengetahuan, sedang logos berarti telaah atau kajian. ${ }^{11}$ Jelasnya, epistemologi berarti kajian tentang pengetahuan, atau kajian yang berhubungan dengan seluk-beluk dan segala sesuatu yang berkaitan dengan pengetahuan. Epistemologi juga biasa dipahami sebagai "teori pengetahuan" (theory of knowledge) yang berarti bagian dari filsafat yang menelaah tentang masalah-masalah yang berhubungan dengan pengetahuan, meliputi sumber, cara dan kriteria sebuah pengetahuan. ${ }^{12}$

Berdasarkan pengertian diatas, maka arah epistemologi yang menjadi landasan dalam tulisan ini akan terfokus pada pengkajian terhadap pemikiran Descartes dari aspek sumber, cara (metode) dan kriteria sebuah pengetahuan (validitasnya). Penjelasan lebih lanjut mengenai hal tersebut dapat disimak sebagaimana analisa di bawah ini:

\section{Sumber dan Hakikat Pengetahuan}

Berbicara mengenai sumber dan hakikat suatu pengetahuan berarti sama halnya berbicara tentang pijakan otoritatif yang dijadikan pegangan oleh seseorang dalam memperoleh sebuah pengetahuan. Descartes yang dijuluki sebagai the founder of modern philosophy memiliki fondasi dasar ajaran filsafat yang sangat populer, yaitu tentang ajaran yang

${ }^{10}$ Fitzerald Kennedy Sitorius, "Rasionalisme René Descartes: Saya Berpikir, maka Saya Ada”, makalah disampaikan dalam Kelas Filsafat Modern di Serambi Salihara, Sabtu 12 Nopember 2016, 4.

${ }^{11}$ Sudarsono, Ilmu Filsafat: Suatu Pengantar, (Jakarta: PT. Rineka Cipta, 2001), 137.

${ }^{12}$ Harold H. Titus, dkk., Persoalan-Persoalan Filsafat, terj. Rasyidi, (Jakarta: Bulan Bintang, 1984), 187-188. 
menegaskan bahwa kebenaran tertinggi berada pada akal budi manusia. Menurutnya, rasio adalah hakikat sumber pengetahuan. Hanya rasio sajalah yang dapat membawa seseorang pada kebenaran. Kebenaran pada dasarnya terletak pada tindakan akal yang cemerlang yang biasa diistilahkan dengan Ideas Claires el Distinctes (pikiran yang terang benderang dan terpilahpilah). ${ }^{13}$ Berkaitan dengan akal sebagai sumber pengetahuan, Descartes kemudian menjelaskan bahwa tujuan hidupnya adalah untuk membimbing akal budi ke arah penemuan kebenaran yang sistematis dan penghapusan kesalahan. ${ }^{14}$

Berangkat dari pemikiran tersebut, Descartes menekankan agar tidak mempercayai segala sesuatu di luar rasio manusia, sebab kesaksian apapun yang bersumber dari luar nalar manusia cenderung bersifat tidak pasti dan tidak dapat dipercaya. Oleh karena itu, kebenaran harus dicari dan didasarkan pada kriteria clearly and distincly. Lebih lanjut, Descartes mengemukakan adanya tiga ide bawaan ${ }^{15}$ (innate ideas) dari setiap masing-masing individu, termasuk dirinya sendiri. Tiga ide bawaan yang dimaksud adalah:

a.Pemikiran: sebab saya memahami diri saya sebagai makhluk berpikir, harus diterima juga bahwa pemikiran merupakan hakikat saya.

b.Allah sebagai wujud sempurna; ketika saya mempunyai ide yang sempurna, maka pasti ada yang sempurna di balik itu. Wujud yang sempurna itu adalah Allah Subhānabu wa Ta'àlā.

c.Keluasan: saya mengerti materi sebagai keluasan atau eksistensi sebagaimana hal ini dilukiskan dan dipelajari oleh pakar ilmu ukur/matematika. ${ }^{16}$

Demi memperkuat gagasannya tersebut dan tidak serta-merta percaya terhadap peran indra, Descartes kemudian menunjukkan pengalaman mimpi yang tampak sangat nyata, bahkan ketika seseorang melakukan sesuatu yang tidak dapat dilakukannya dalam keadaan sadar-semisal terbang - maka hal itu nampak ia sungguh bisa melakukannya. Oleh sebab itulah, tidak ada sesuatu apapun yang dapat menyakinkan seseorang bahwa dirinya pada saat itu tidak sedang bermimpi. Dan jika seseorang tidak bisa yakin bahwa dirinya tidak sedang bermimpi kala itu, maka sesungguhnya ia tidak bisa memperoleh pengetahuan melalui penggunaan indranya. ${ }^{17}$

\section{Metode Pengetahuan}

Untuk memperoleh kebenaran sebuah pengetahuan dan memastikan bahwa obyek yang diamati memang benar-benar ada dan bukan merupakan sebuah khayalan, maka Descartes menggunakan metode yang disebutnya sebagai metode keraguan (the method of Chartesian Doubt). Metode ini sebenarnya bukanlah merupakan teori baru yang digagas Descartes dalam filsafatnya. Dalam tradisi Islam, al-Ghazālī (w. 1111 M.) sudah lebih awal memperkenalkan metode itu dalam filsafat yang dikembangkannya. ${ }^{18} \mathrm{Jadi}$, metode Descartes ini pada hakikatnya tidaklah asing dalam tradisi filsafat Islam.

Metode keraguan Descartes adalah suatu langkah dimana ia mengawali upaya menyangsikan segala sesuatu. Penyangsian ini beralasan bahwa tidak semua hal dipandang sebagai pengetahuan yang benar. Terdapat beberapa kenyataan yang sering kali tertipu oleh pengamatan, seperti argumen Plato yang menyatakan bahwa tongkat yang terdapat di dalam

\footnotetext{
${ }^{13}$ Cahaya Khaeroni, "Epistemologi Raionalisme Rene Descartes dan Relevansinya terhadap Pendidikan Islam", dalam Didaktika Religia, vol. 2, no. 2, 2014, 188.

${ }^{14}$ Muhamad Syaikhu Abdulah, "Ibn Rusyd dan Rene Descartes: Studi Komparatif tentang Rasionalitas", (Skripsi di UIN Walisongo, Semarang, 2013), h. 88.

${ }^{15}$ Ide-ide bawaan (innate ideas) adalah serangkaian ide yang ada pada diri manusia, dan bukan merupakan sesuatu yang diperoleh dari pengalaman yang mengutamakan sifat-sifat rasionalnya.

${ }^{16}$ Ngismatul Choiriyah, "Rasionalisme Rene Descartes", dalam Anterior Jurnal, vol. 13, no. 2, 2014, h. 241.

${ }^{17}$ Cahaya Khaeroni, "Epistemologi Raionalisme Rene Descartes dan Relevansinya terhadap Pendidikan Islam”, h. 189.

${ }^{18}$ Lihat keterangan lebih lanjut mengenai perbandingan metode filsafat al-Ghazālī dan Descartes dalam: Maḥmūd Hạdī Zaqzūq, al-Manhaj al-Falsafì baina al-Ghazālī wa Descartes, (Kairo: Dār al-Ma’ārif, t.th).
} 
air bergelombang kelihatan bengkok; jalan lurus diujungnya kelihatan menyatu, dan seterusnya. Descartes terus menyangsikan segala hal, meski sekecil apapun. ${ }^{19}$ Dari kesangsiannya itu, ia kemudian mengajukan beberapa unsur metodologis yang dapat menjadi landasan berpikir dalam menetukan sebuah kebenaran sebagai berikut:

a. Tidak menerima apapun sebagai hal yang benar, kecuali jika diyakini sendiri bahwa itu memang benar.

b. Memilah-milah masalah menjadi bagian-bagian terkecil untuk mempermudah penyelesaian.

c. Berpikir runtut dengan memulai dari hal yang sederhana, sedikit demi sedikit untuk sampai pada suatu hal yang paling rumit.

d. Perincian yang lengkap dan pemeriksaan menyeluruh sangat diperlukan agar tidak ada yang terlupakan. ${ }^{20}$

Keragu-raguan yang dipraktikkan Descartes bukan semata-mata demi keraguan, tetapi sebagai tahap awal dalam mencapai sebuah kepastian. Ia berkomentar bahwa adanya saya ragu berarti secara langsung membuktikan adanya saya berpikir. Penyataan ini dalam perspektif Descartes menyebutnya sebagai istilah cogito ergo sum (saya berpikir, maka saya ada). Perlu dicatat bahwa isi dari cogito adalah apa yang dinyatakan semata-mata dari dirinya yang berpikir. "Saya berpikir, maka saya ada" adalah pengada berpikir, yaitu eksistensi dari budi yang timbul melalui substansi kesadaran. Namun hal ini tidak menjamin eksistensi dari badan. Singkatnya, ketika Descartes berbicara mengenai "berpikir", maka ia tidak memaksudkan secara ekslusif pada penalaran saja, melainkan melihat, merasa, mendengar, senang atau susah, kehendak, yang dianggap sebagai kegiatan sadar juga termasuk dalam ranah istilah "berpikir". Meskipun mungkin status dari objek-objek mereka dapat diragukan, namun aktivitas kesadaran dari objek itu tidak diragukan. Dan perlu dicatat pula bahwa cogito bukanlah dicapai melalui penyimpulan, dan ergo bukanlah ergo silogisme. Jadi yang dimaksud Descartes adalah bahwa eksistensi personal saya yang penuh diberikan kepada saya dalam kegiatan meragukan terhadap segala sesuatu. ${ }^{21}$

Cogito ergo sum yang berarti saya berpikir, maka saya ada, dalam perspektif penulis mempunyai kesamaan dengan syair Arab yang berbunyi:

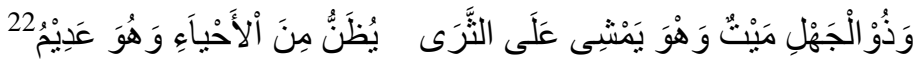 \\ Orang bodoh tak ubahnya seperti mayat yang berjalan di muka bumi, namun eksistensisnya dianggap nibil.}

Syair tersebut jika dijabarkan mengandung makna bahwa kebodohan adalah entitas dari tidak adanya kegelisahan jiwa untuk berpikir. Akibatnya, meskipun secara kasat mata ia dianggap ada, namun pada hakikatnya ia sama sekali tidak ada, sebab peluang aktivitas berpikir tidak dimaksimalkan dengan baik. Berpikir merupakan identitas mutlak manusia sebagai makhluk hidup yang benar-benar hidup. Satu hal inilah yang membedakan keistemewaan manusia dengan makhluk lain. Munculnya berpikir sendiri berasal dari kegelisahan atau keragu-raguan terhadap adanya segala sesuatu. Descartes telah mengawali proses ini dengan berbagai tahapan yang ditempuhnya. Ahmad Tafsir telah menyusun tahapan-tahapan pola berpikir Descartes ke dalam sebuah bagan sebagai berikut:

${ }^{19}$ Cahaya Khaeroni, "Epistemologi Raionalisme Rene Descartes dan Relevansinya terhadap Pendidikan Islam", h. 190.

${ }^{20}$ Ibid, h. 192.

${ }^{21}$ Kenneth T. Gallagher, Epistemologi: Filsafat Pengetahuan, terj. Hardono Hadi, (Yogyakarta: Kanisius, 1994), h. 33.

${ }^{22}$ Tanpa pengarang, Alālā Tanāl al-'Ilm, (Surabaya: Maktabah Muḥammad ibn Aḥmad Nabhān wa Aulāduh, t.th), h. 4. 


\section{Sistematika Tahapan Metode Cogito Descartes ${ }^{23}$}

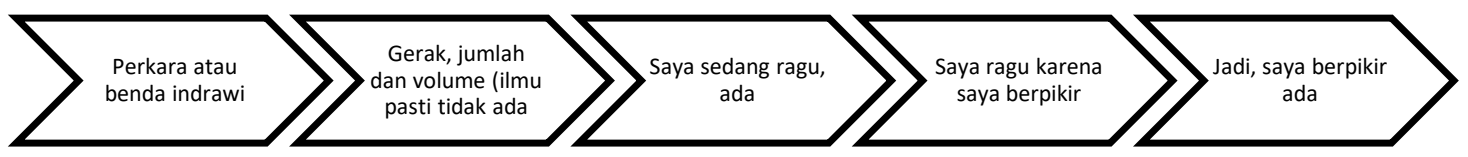

Selain metode keraguan (the method of Chartesian Doubt), dalam memperoleh pengetahuan yang benar dan pasti, Descartes juga menggunakan metode intuisi dan deduksi. Intuisi dalam perspektif Descartes adalah konsepsi mengenai sesuatu yang jelas dan pasti dalam pikiran serta berbeda dengan konsepsi lain, sehingga tidak ada keraguan sedikitpun mengenai kebenaran pemahaman tentang konsepsi tersebut. Dengan kata lain, intuisi adalah konsepsi dalam pikiran yang kebenarannya tidak diragukan lagi dan konsepsi tersebut semata-mata muncul dari rasio. Sedangkan deduksi adalah penarikan kesimpulan dari beberapa proposisi yang diketahui secara pasti. Melalui deduksi, seseorang dapat menarik kesimpulan atau konsekuensi-konsekuensi yang pasti dari obyek yang diketahui secara jelas dan terpilah-pilah, atau dari intuisi. Dengan kata lain, deduksi dilakukan atas intuisi. Dan intuisi merupakan titik tolak dari deduksi. Intuisi sendiri adalah pengetahuan yang pasti mengenai obyek, dan deduksi kemudian dilakukan dengan bertolak dari apa yang diketahui secara pasti tersebut. Dalam konsepsi Descartes, intuisi pada dasarnya tidak menghasilkan pengetahuan. Pengetahuan yang benar hanya muncul melalui deduksi atas intuisi itu sendiri. Descartes menunjukkan cara kerja metode intuisi dan deduksi pada saat dirinya mendeduksikan konsep Tuhan dan res extensa (benda berkeluasan) dari konsep cogito. ${ }^{24}$

Dengan demikian, baik metode intuisi maupun deduksi, meskipun keduanya berbeda, tetapi saling mengandaikan dalam sebuah proses pencarian pengetahuan yang pasti akan kebenarannya. Intuisi tidak memerlukan pergerakan pemikiran. Namun deduksi yang dilakukan atas intuisi tersebut harus dilakukan dengan sangat cermat dan hati-hati, selangkah demi selangkah, dengan tidak membiarkan apapun yang meragukan masuk ke dalam rasio, sehingga proses ini akan mampu melahirkan pengetahuan atau proposisi yang dideduksikan dari intuisi tersebut bersifat pasti (pengetahuan penting). Khaeroni, dalam hal ini menggambarkan cara kerja dua metode ini (intuisi dan deduksi) sebagai berikut: ${ }^{25}$

\section{(Melalui intuisi, misalnya "saya berpikir, maka saya ada")}

Skeptisisme

Metodologis

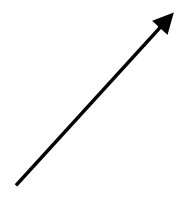

Pengetahuan

General

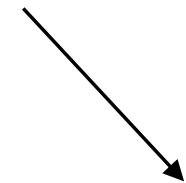

Deduksi
Pengetahuan

Penting

Pengetahuan

(Opini-opini/Proposisi)

Murni

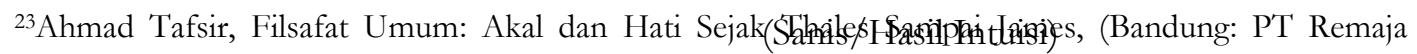
Rosdakarya, 1997), h. 115.

${ }^{24}$ Fitzerald Kennedy Sitorius, "Rasionalisme René Descartes: Saya Berpikir, maka Saya Ada", h. 8.

${ }^{25}$ Cahaya Khaeroni, "Epistemologi Raionalisme Rene Descartes dan Relevansinya terhadap Pendidikan Islam”, h. 192. 


\section{Validitas Pengetahuan Descartes}

Klaim terhadap validitas sebuah pengetahuan harus diukur berdasarkan teori-teori kebenaran dalam Filsafat Ilmu. Termasuk dalam hal ini terkait validitas pengetahuan Descartes. Dalam kajian filsafat, paling tidak ada tiga teori kebenaran yang populer untuk menguji validitas sebuah pengetahuan. Tiga teori yang dimaksud adalah teori koherensi, teori korespondensi, dan teori pragmatisme.

Teori koherensi menyatakan bahwa standar kebenaran itu tidak dibentuk oleh hubungan antara pendapat dengan sesuatu yang lain (fakta atau realitas), tetapi dibentuk oleh hubungan internal (internal relation) antara pendapat-pendapat atau keyakinan-keyakinan itu sendiri. Dengan kata lain, sebuah pengetahuan itu dianggap benar jika ada konsistensi logisfilosofis dengan proposisi-proposisi yang dibangun sebelumnya. Sedangkan teori korespondensi menyatakan bahwa "suatu proposisi itu dianggap benar jika terdapat suatu fakta yang memiliki kesesuaian dengan apa yang diungkapkannya". Atau juga didefinisikan bahwa kebenaran dalam teori korespondensi sebagai "kesepakatan atau kesesuaian antara pernyataan suatu fakta (keputusan) dengan situasi lingkungan yang diinterpretasikannya. Adapun teori pragmatisme menyatakan bahwa suatu proposisi dianggap benar sepanjang ia berlaku atau memuaskan, yang digambarkan secara beragam oleh perbedaan pendukung dan pendapat. ${ }^{26}$

Berdasarkan tiga teori kebenaran di atas, maka teori yang relevan untuk mengukur validitas pemikiran Descartes adalah teori koherensi. Dikatakan demikian, sebab menurutnya pengetahuan yang paling pertama dan paling pasti yang diperoleh setiap orang berfilsafat adalah melalui cara berpikir yang sistematis. Akal sehat seseorang mungkin berkata bahwa dunia fisik eksternal di sekitarnya yang diketahui melalui indra merupakan hal yang paling pasti dibandingkan dengan pikiran yang tidak terlihat. Namun menurut Descartes, "kita tidak mempersepsi benda-benda eksternal melalui indra atau imajinasi, melainkan melalui proses yang sama dengan proses intelektual murni yang dapat memberi pengetahuan mengenai diri kita yang eksis sebagai makhluk berpikir". Dengan kata lain, dalam mempersepsi dunia eksternal yang mungkin belum pasti, kita telah selalu memiliki kepastian mengenai kita yang mempersepsi atau berpikir tentng dunia eksternal tersebut. Dari sini Descartes menyimpulkan bahwa pengetahuan kita yang paling pertama dan paling pasti bukanlah mengenai obyek-obyek yang kita persepsikan di luar, melainkan mengenai pikiran kita. Oleh karena itu, pikiran kita mengenai sebuah pengetahuan bersifat mendahului dan lebih pasti dibandingkan dengan pengetahuan kita mengenai benda-benda eksternal, sebab kita telah selalu menyadari (pikiran) itu, sekalipun kita masih ragu terhadap hal-hal lain di luar kita. ${ }^{27}$

\section{Relevansi Rasionalitas Rene Descartes dalam Ranah Penafsiran al-Qur’an}

Dari deskripsi tentang konsep pemikiran Descartes di atas, setidaknya disana ditemukan sekelumit konsep yang mempunyai titik relevansi dengan diskursus penafsiran alQur`an. Menurutnya, sumber yang paling otoritatif untuk memperoleh sebuah pengetahuan adalah akal atau rasio. Ini jika dikaitkan dalam ranah penafsiran al-Qur`an, maka sama halnya dengan tafsir bi al-ra $y z^{28}$ Namun perlu dicatat bahwa hasil penafsiran bersifat relatif dan

\footnotetext{
${ }^{26}$ Abdul Mustaqim, Epistemologi Tafsir Kontemporer, (Yogyakarta: LKiS, 2010), h. 291-297.

${ }^{27}$ Rene Descartes, Mabādi` al-Falsafah, terj. 'Utsmān Amīn, (t.t.: Dār al-Tsaqāfah, t.th), h. 84.

${ }^{28}$ Tafsir bi al-ra yī adalah suatu langkah di mana seorang mufasir mengerahkan akalnya untuk memahami al-Qur`an dan menggali pesan-pesan yang terkandung di dalamnya dengan menggunakan
} 
hakikat kebenarannya hanya Allah yang mengetahui. Jadi, akal manusia hanya berperan menafsirkan ayat-ayat al-Qur'an sesuai dengan kapasitasnya masing-masing tanpa adanya pengakuan bahwa penafsirannya itulah yang paling benar.

Di samping itu, jika konsep pemikiran Descartes hanya berpijak pada akal, maka tidak halnya dengan tafsir bi al-ra yì, sebab memurnikan peran akal saja dalam menafsirkan alQur an tanpa mempertimbangkan aspek lain yang berkaitan dengan riwayat-riwayat merupakan suatu langkah yang dianggap telah menyimpang dari kode etik penafsiran itu sendiri. Terkait hal ini, Rasulullah Șalla Allah 'Alaybi wa Sallam telah memperingatkan melalui sabdanya sebagai berikut:

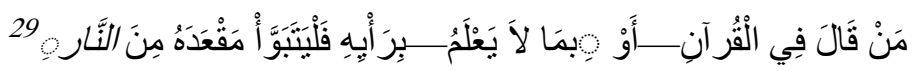

Barang siapa yang yang berkata (menafsirkan) al-Qur'an-atau dengan perkara yang tidak diketabuinya — dengan rasionya, maka ia sedang berkehendak bertempat di neraka.

Berdasarkan instruksi tersebut, sejumlah sarjana muslim mengecam keras praktik penafsiran bi al-ra 'yi. Bahkan, mereka mengklaim "sesat" atas akal yang digunakan sebagai instrumen utama dalam sebuah penafsiran, sehingga tidak jarang model penafsiran ini disebut dengan istilah tafsir bi al-haw $\bar{a}^{30}$ Terlepas dari penolakan ini, sederet sarjana muslim lain menerimanya meskipun dengan mengajukan beberapa syarat dan ketentuan yang harus dipatuhi. Al-Dzahabī misalnya, mengemukakan lima hal yang harus dihindari mufasir manakala menafsirkan al-Qur an bi al-ra yzi: pertama, menjauhi sikap terlalu berani mendugaduga kehendak Allah di dalam firman-Nya, tanpa memiliki persyaratan sebagai mufasir. Kedua, memaksakan diri menafsirkan ayat yang hanya menjadi wewenang Allah dalam mengetahuinya. Ketiga, menghindari dorongan dan keinginan hawa nafsu. Keempat, menghindari penafsiran dengan tujuan untuk melegitimasi kepentingan mazhab. Kelima, menghindari penafsiran pasti (qați) di mana seorang mufasir mengklaim bahwa hanya penafsirannya merupakan satu-satunya yang dimaksud oleh Allah. ${ }^{31}$

Penafsiran dengan menggunakan akal sebagai alat untuk mengungkap pesan-pesan Ilahi yang terkandung di dalam al-Qur`an, pada dasarnya tidak hanya bertumpu pada akal secara mutlak. Dalam kenyataannya, para mufasir yang berangkat dari penafsiran ini juga bertolak dari pemahamannya terhadap nilai-nilai sunah Nabi. Hanya saja mereka tidak terlalu mengekang diri dengan keharusan merujuk pada riwayat-riwayat. Adanya penafsiran bi alra jy, justru memberikan angin segar bagi berkembangnya corak penafsiran yang sangat variatif, semisal corak tafsìr falsafì, 'ilmi, fiqhī dan yang lainnya. Banyaknya corak penafsiran yang terlahir dari rahim tafsir bi al-rayz, membuat semakin marak bermunculan karya-karya tafsir di berbagai kalangan. Tentu, hal ini tidak saja memberikan perbendaharaan pengetahuan yang luas bagi masyarakat muslim, tetapi sekaligus juga sebagai bukti tingginya khazanah peradaban muslim dalam aspek pengetahuan terhadap interpretasi al-Qur`an.

Dewasa ini, dalam konteks kemajuan ilmu pengetahuan dan multikulturalisme, tafsir bi al-ra'yi atau bi al-'aqli dipandang lebih mampu mengakomodir dalam menjawab isu-isu kekinian. Dalam kajian kontemporer, tafsir bi al-ra yi secara operasional dapat dikategorikan sebagai cara pandang penafsiran dengan menggunakan pendekatan ilmu-ilmu sosial modern, semisal pendekatan hermeneutika, stilistika, antropologi, sosio-linguistik, dan fenomenologi.

instrumen berupa media ijtihad. Term tafsir bi al-ra ȳ̄ bersinonim sama dengan tafsir aqlī atau tafsir ijtihādī. Lihat, Musā’id ibn Sulaimān al-Ṭayyār, Maqālāt fî 'Ulūm al-Qur’ān wa Ușūl al-Tafsīr, (Riyāọ: Dār al-Muhaddits, 1425 H), h. 209.

${ }^{29}$ Hadis ini menurut penilaian al-Tirmidzī berstatus ḥasan. Lihat, Mannā’ al-Qaț̣āan, Mabāḥits fì 'Ulūm al-Qur`ān, (Kairo: Maktabah Wahbah, t.th), h. 342.

${ }^{30}$ Aḥmad ibn 'Abd al-Rahīm al-Dihlawī, al-Fauz al-Kabīr fì Uṣūl al-Tafsīr, (Damaskus: Dār alGhautsānī, 2008), h. 14.

${ }^{31}$ Muḥammad Ḥusain al-Dzahabī, al-Tafsīr wa al-Mufassirūn, jilid I (Kairo: Maktabah Wahbah, t.th), h. 196. 
Berbagai pendekatan ini dipandang signifikan di era sekarang, sebab penafsiran yang dihasilkan akan lebih akomodatif dan relevan li kulli zamān wa makān.

\section{Simpulan}

Dari kajian singkat mengenai epistemologi rasionalisme Rene Descartes, dapat penulis simpulkan bahwa sumber pengetahuan yang diperoleh Descartes adalah melalui akal atau rasio. Sementara metode yang digunakannya adalah metode intuisi dan deduksi, dan juga metode keraguan (the method of chartesian doubt). Adapun tolok ukur kebenarannya diukur melalui teori koherensi. Epistemologi rasionalisme Descartes pada dasarnya mempunyai relevansi dengan tradisi penafsiran al-Qur an. Titik relevansinya terletak pada akal sebagai alat untuk mencari pengetahuan. Dalam konteks tafsir, akal juga menjadi alat untuk mengungkap pesan-pesan Ilahi yang terkandung di dalam al-Qur'an. Penggunaan akal ini dalam diskursus penafsiran biasanya dikenal dengan istilah tafsir bi al-ra'yì atau bi al-'aqlì.

\section{Daftar Pustaka}

Abdulah, Muhamad Syaikhu, (2013). "Ibn Rusyd dan Rene Descartes: Studi Komparatif tentang Rasionalitas". Skripsi di UIN Walisongo. Semarang.

Bagus, Loreus, (2002). Kamus Filsafat. Jakarta: Gramedia Pustaka Utama.

Choiriyah, Ngismatul, (2014). "Rasionalisme Rene Descartes". dalam Anterior Jurnal. vol. 13, no. 2.

Descartes, Rene. Mabādi` al-Falsafah. terj. 'Utsmān Amīn. t.t.: Dār al-Tsaqāfah. t.th

Dihlawī (al-), Aḥmad ibn 'Abd al-Rahīm, (2008). al-Fauz al-Kabīr fì Ușūl al-Tafsīr.

Damaskus: Dār al-Ghautsān̄î.

Dzahabī (al-), Muḥammad Husain. al-Tafsīr wa al-Mufassirūn. Kairo: Maktabah Wahbah. t.th

Esposito, John L. (ed.). The Oxford Encyclopedia of the Modern Islamic World. New York: Oxford University Press, t.th. vol. 3

Gallagher, Kenneth T, (1994). Epistemologi: Filsafat Pengetabuan. terj. Hardono Hadi. Yogyakarta: Kanisius.

Harold H. Titus, dkk., (1984). Persoalan-Persoalan Filsafat. terj. Rasyidi. Jakarta: Bulan Bintang.

Khaeroni, Cahaya, (2014). "Epistemologi Raionalisme Rene Descartes dan Relevansinya terhadap Pendidikan Islam". dalam Didaktika Religia. vol. 2, no. 2.

Mustaqim, Abdul, (2010). Epistemologi Tafsir Kontemporer. Yogyakarta: LKiS.

Qatțān (al-), Mannā’. Mabāḥits fī 'Ulūm al-Qur’ān. Kairo: Maktabah Wahbah. t.th

Sholehah Yaacob dan Hairunnaja Najmuddin, (2008). "Rene Descartes dan Metode Cogito". dalam Jurnal Ushuluddin. vol. 27.

Sitorius, Fitzerald Kennedy, (2016). "Rasionalisme René Descartes: Saya Berpikir, maka Saya Ada". makalah disampaikan dalam Kelas Filsafat Modern di Serambi Salihara. Sabtu 12 Nopember.

Strathern, Paul, (2001). 90 Menit Bersama Descartes. terj. Fans Kowa. Jakarta: Erlangga.

Sudarsono, (2001). Ilmu Filsafat: Suatu Pengantar. Jakarta: PT. Rineka Cipta.

Suseno, Franz Magnis, (2002). Filsafat sebagai Ilmu Kritis. Yogyakarta: Kanisius.

Tafsir, Ahmad, (1997). Filsafat Umum: Akal dan Hati Sejak Thales Sampai James. Bandung: PT Remaja Rosdakarya.

Tanpa pengarang, Alālā Tanāl al-'Ilm. Surabaya: Maktabah Muḥammad ibn Aḥmad Nabhān wa Aulāduh. t.th

Ṭayyār (al-), Musā’id ibn Sulaimān (1425 H). Maqāāāt fî 'Ulūm al-Qur'ān wa Ușūl al-Tafsīr. Riyāẹ: Dār al-Muhaddits.

Teng, Muhammad Bahar Akkase, (2016). "Rasionalis dan Rasionalisme dalam Perspektif Sejarah". dalam Jurnal Ilmu Budaya. vol. 4, no. 2, Desember. 
Widoyono, Penyakit Kronis: Epidemiologi, Penularan, Pencegaban dan Pemberantasannya. Jakarta: Erlangga. t.th

Zaqzūq, Maḥmūd Ḥamdī. al-Manhaj al-Falsafì baina al-Ghazālī wa Descartes. Kairo: Dār alMa'āifif. t.th 

Mochammad Arifin

Rasionalisme 31 